\title{
CLARK'S GREBES AND SUSPECTED WESTERN X CLARK'S GREBE HYBRIDS IN MANITOBA
}

BRUCE A. EICHHORST and BARRY D. PARKIN, Department of Biology, Box 8238, University of North Dakota, Grand Forks, North Dakota. 58202

The Clark's Grebe was recently resurrected to species rank, as originally described by George N. Lawrence in $1858{ }^{2,4}$ Prior to 1985 , it was considered a colour phase of the Western Grebe. ${ }^{1}$ These two grebes overlap considerably through much of their ranges, but the frequency of Clark's Grebes in Canadian populations is generally considered to be much less than $1 \%{ }^{5}$ To date, no more than six Clark's Grebes have been reported from any one Canadian site, and the first documented nesting occurred in 1986 at Pelican Lake,
Manitoba. ${ }^{5}$ In this paper we report on our observations of Clark's Grebes and suspected Western X Clark's hybrids on the East Delta Marsh, Manitoba.

From 8 June to 1 July 1989, we visited the Delta Waterfowl and Wetland Research Station to collect grebes for a study on genetic variation. The Delta Marsh system is located at the southem end of Lake Manitoba and consists of three management units. We restricted our work to a portion of the east unit (hereafter referred to as the East Marsh;

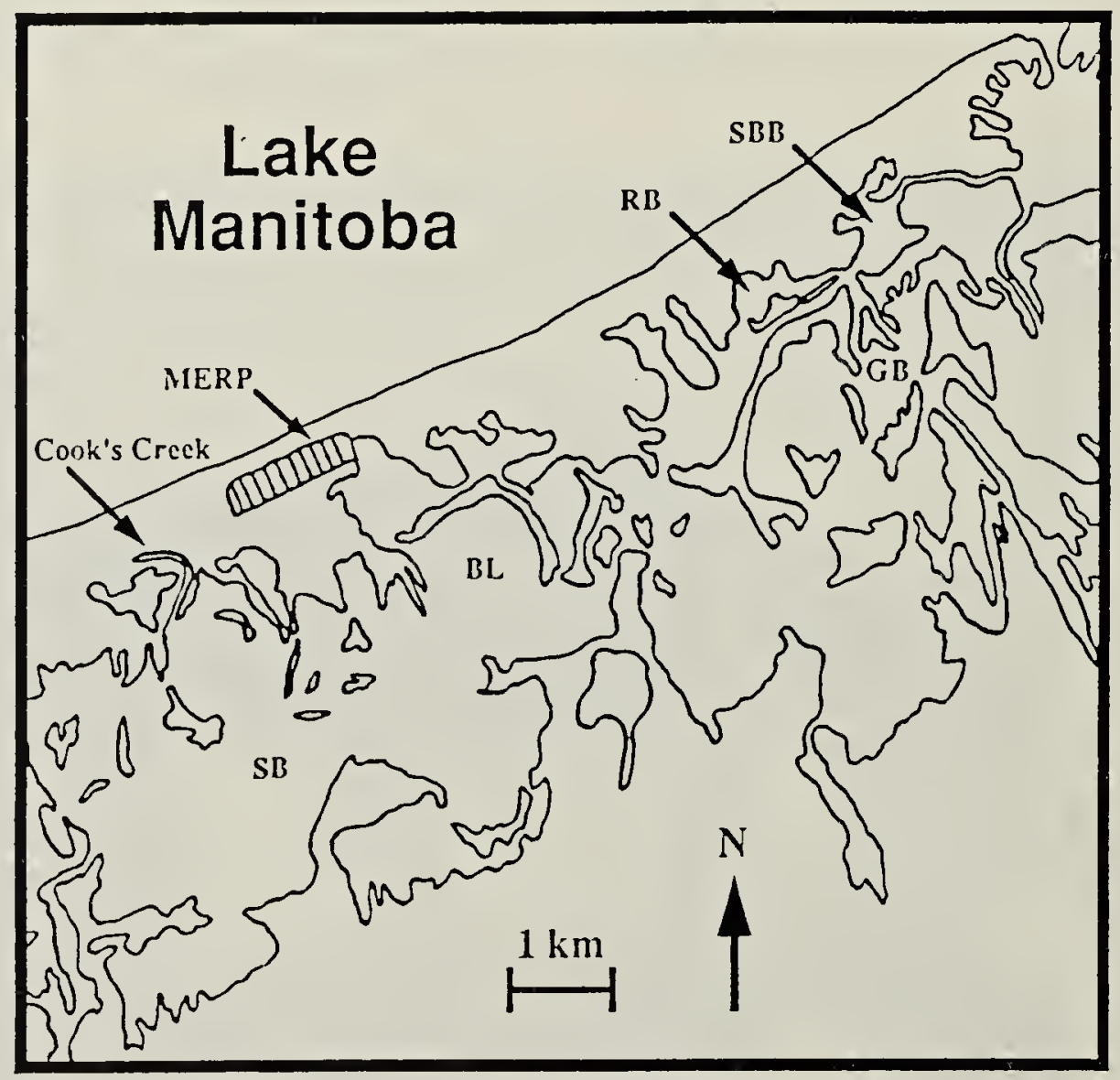

Figure 1. Location of four areas (BL, $G B, R B$, and $S B B)$ on the East Delta Marsh, Manitoba where Clark's Grebes and intermediates were observed in 1989. BL, Blackfox Lake; GB, Gadwell Bay; RB, Riley's Bay; SB, Simpson Bay; SBB, Small Bluebill Bay; MERP, Delia's Marsh Ecology Research Project area. 
see Fig. 1). The East Marsh, which contains a series of interconnected large and small shallow bays is described in detail elsewhere, and the nesting ecology of Western Grebes on the East Marsh has also been described. $3,10,13$

Our first sighting of Clark's Grebes occurred the morning of 8 June, when we canoed through Simpson Bay and then went east to Blackfox Lake. We observed five Clark's (two pairs and one individual) at Blackfox Lake. During the afternoon of the same day, we observed five additional Clark's as we canoed through Riley Bay and Small Bluebill Bay (Fig. 1).

During the 20 days that we spent on the East Marsh, we observed Clark's Grebes in four areas that contained Western Grebe colonies. Blackfox Lake supported the largest number of Clark's; nine separate individuals were observed on 19 June. We were able to locate four Clark's nests at Blackfox Lake. In Small Bluebill Bay we observed one pair of Clark's on 8 June and observed a single Clark's at a nest on 16 June. On 13 June we observed four Clark's in Gadwell Bay and observed two Clark's at a nest on 18 June. In Riley Bay we observed three Clark's on 8 June and located one nest on 14 June.

Of the 18 Clark's Grebes that we observed, three of them were lived-trapped at their nests. The first Clark's we trapped was from the above-mentioned Riley Bay nest. It was a female that was paired with a suspected hybrid male, which we trapped on the same attempt (Fig. 2). The other Clark's that we trapped were from two separate nests on Blackfox Lake.

We observed suspected hybrids (i.e. intermediate-facial plumage and/or bill colour) in those areas of the East Marsh that contained Clark's Grebes. Adults that have intermediate facial/bill characters are possible hybrids, but it has yet to 49(4). December 1991 be confirmed by raising known hybrid chicks. We collected nine such intermediates and observed at least that many more.

In the intermediates that we collected, the black of the crown either bisected the eye or extended just below the eye, and the colour of the lores ranged from darkgrey to white. Bill colour ranged from dull greenish-yellow to a dull yellowishorange, which can best be described as intermediate between the bright orangeyellow typical of Clark's and the dull greenish-yellow typical of Westerns. All intermediates collected had some orange on the lower mandible, mainly on the ventral surface near the base. On the black and white photograph (Fig. 3) of the intermediate male, the area of orange is not readily discernable. However, in the literature there are some colour photographs of intermediates that illustrate this bill colour characteristic. Szafranski's photograph of three adults rushing across the water, illustrates the difference between the bill colour of typical Westerns (male and female pictured on the left and the right, respectively) and the bill colour of an intermediate (male in the middle). ${ }^{12}$ The orange area of the intermediate's lower mandible is quite noticeable; the overall bill colour is dull yellowish-orange and the black crown bisects the eye. The thin patch of bare skin, which extends from the base of the upper mandible to the eye, is also orange. We found this patch of skin to be dark green in Westerns, orange in Clark's, and variable in intermediates. In Nuechterlein's photograph of an intermediate female sitting on a nest with chicks, the orange area of the lower mandible appears to be small and restricted to the base area. ${ }^{11}$ Overall bill colour is that of a typical Western and the black crown bisects the eye. However, in comparison to Szafranski's intermediate, the lores are whitish.

Based on our observations, at least 18 Clark's Grebes and 18 intermediates (i.e. 


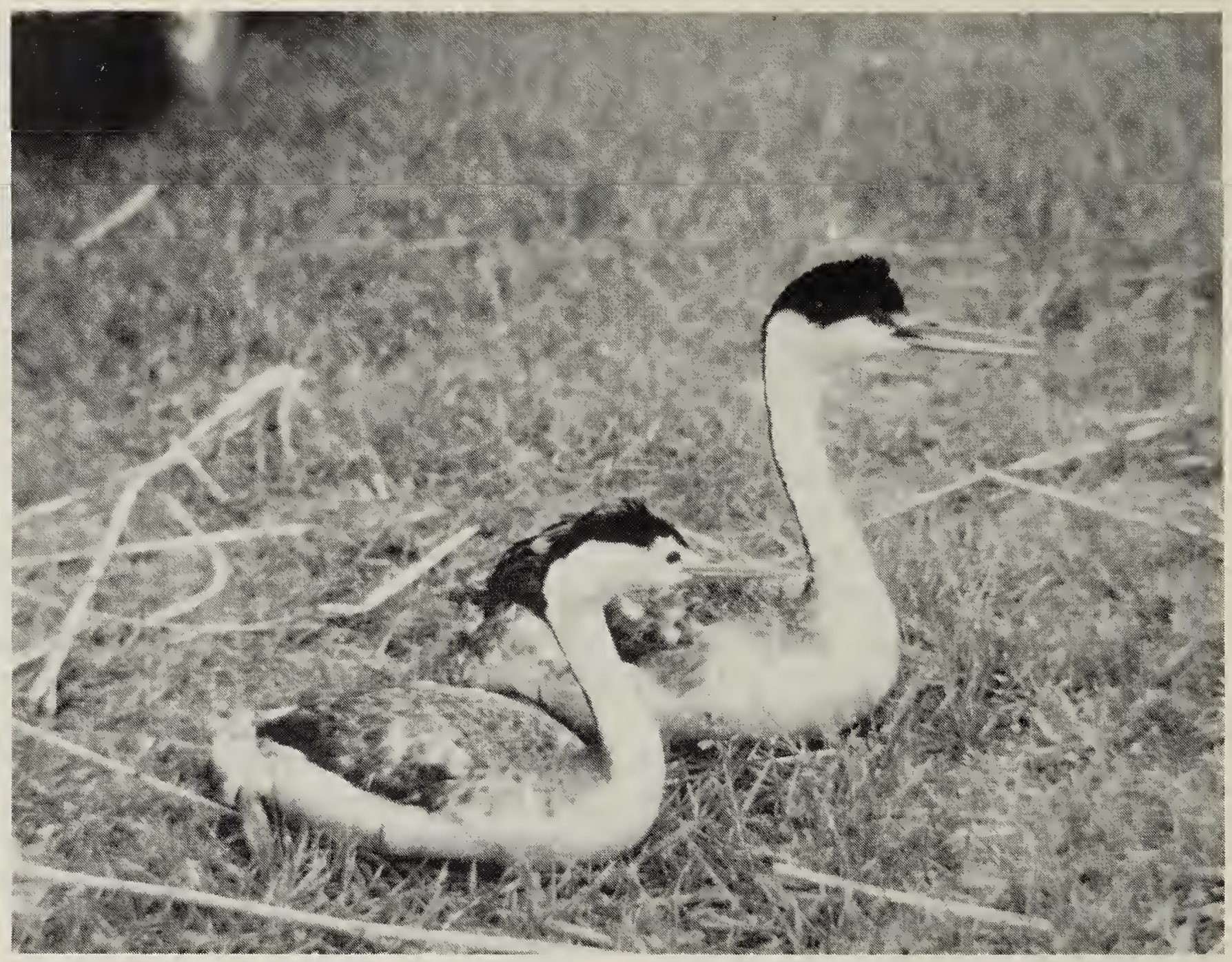

Figure 2. Female Clark's Grebe mated with intermediate male. Pair was trapped at their nest in Riley Bay on 20 June, 1989.

Bruce Eichhorst

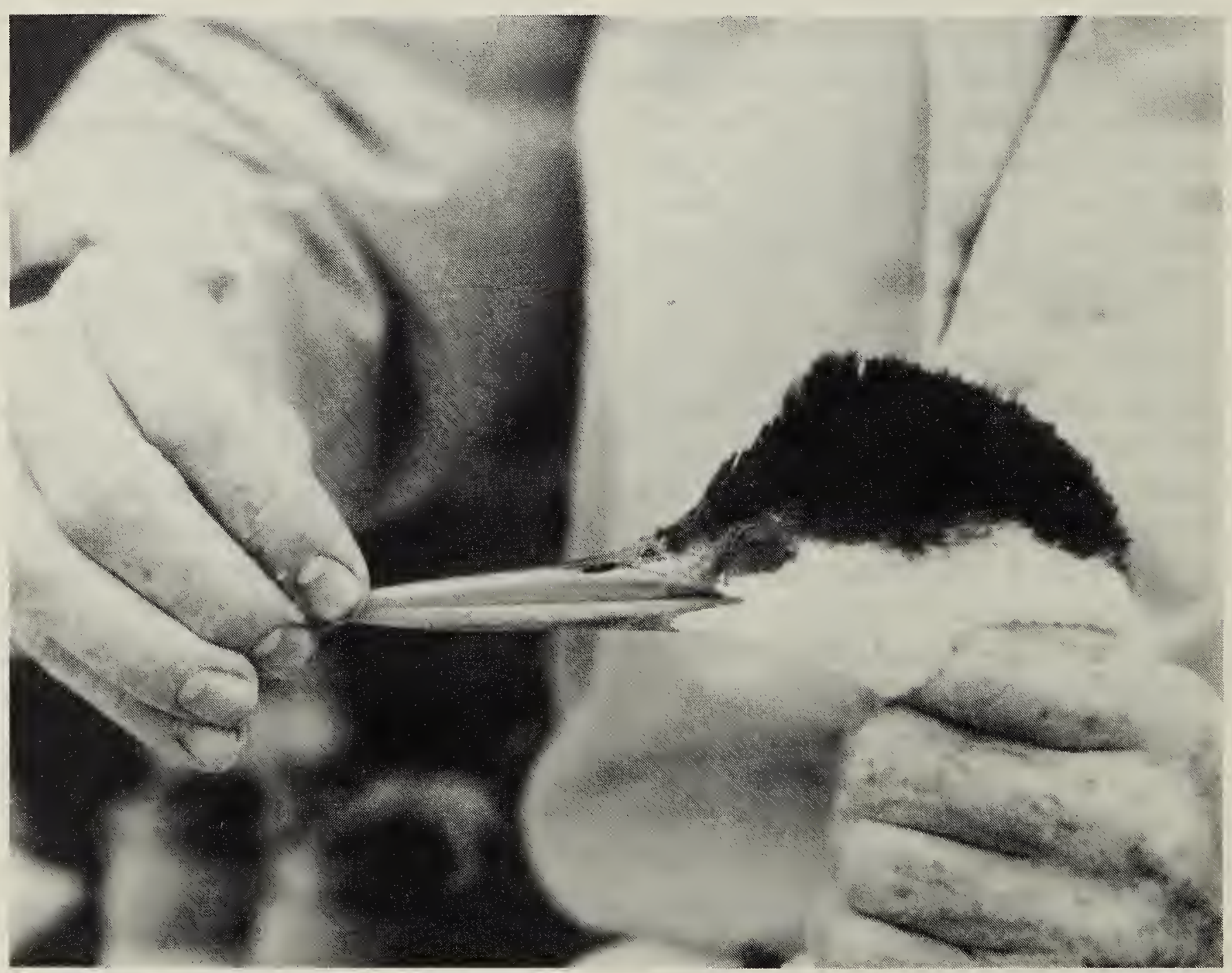

Figure 3. Close-up of intermediate male.

Bruce Eichhorst 
suspected hybrids), were present in the combined areas of Blackfox Lake, Riley Bay, Small Bluebill Bay, and Gadwell Bay. Because of the large size of the East Marsh (4,620 ha of main water bodies) and our mode of transport (canoe), we restricted our efforts to those four areas. Since no attempt was made to locate all nesting colonies, it is probable that more than 18 Clark's were present on the East Marsh in 1989. ${ }^{3}$ We estimate that approximately 1,000 to 1,500 grebes were present in those four areas, which would put the frequency of Clark's between $1.2 \%$ and $1.8 \%$; among the highest documented for Canadian populations. This raises the question of whether Clark's have always been present at this frequency, or whether the frequency we observed is the result of recent movements northward from southem populations. We believe it is the latter. Nuechterlein studied the nesting ecology of Western Grebes on the East Marsh from 1973-1974, but did not observe any Clark's (pers. comm.). During his behavioral studies, most of which were conducted at Marshy Point, Manitoba, from 1975-1979, he observed one Clark's each at Delta's East Marsh and Marshy Point (pers. comm.). During a visit to the East Marsh in 1986, he observed one pair of Clark's (pers. comm.). ${ }^{5}$

The recent (1987-1991) drought in the western U.S. has reduced the number of suitable nesting areas for Clark's Grebes (unpubl. information from various state wildlife agencies; Eichhorst, pers. obs.). In addition, important Clark's nesting habitat was recently lost at the Bear River Migratory Refuge, Utah, when Great Salt Lake experienced consecutive record-breaking lake level rises from $1983-19866^{6}$ It is very probable that Clark's have responded to these changes/losses by migrating further north than usual to find suitable nesting habitat.
In Saskatchewan, six Clark's were observed at the north end of Last Mountain Lake on 14 and 15 June 1988; and on 1 June 1989, five were reported in the same area among 323 Westerns. ${ }^{8,9}$ In July 1990, three Clark's Grebe families were observed at the Valeport Marsh. ${ }^{10}$ De Smet observed at least five Clark's in 1986 on Pelican Lake, Manitoba, in a colony of about 500 Westerns. ${ }^{5}$ Two Clark's were observed there in 1987 and three in $1988 .^{7,8}$ We surveyed Pelican Lake on 3 June 1989, and observed fewer than 20 Westerns on the entire lake. A local resident informed us that Western Grebes had arrived in early spring but departed shortly thereafter. The grebes most likely departed due to the water levels in the bulrush (Scirpus spp.) beds, which were too low for nesting (pers. obs.). If any Clark's were among the arriving Westerns they may have continued northward, possibly ending up at the East Marsh.

As De Smet stated, "Western Grebe colonies throughout Canada need to be more carefully scrutinized to better understand the status and distribution of the Clark's Grebe." We strongly encourage birders and ornithologists to venture out into Canada's marshes to search for and count Clark's Grebes. Such data will help document local and regional changes over time, and will provide much needed information on topics such as hybridization rates (i.e., count adult intermediates or mixed pairs with young). In addition, current information on the status and distribution of Western Grebe colonies is needed, especially for Alberta. If you have unpublished information on Westerns, Clark's, mixed pairs, and/or intermediates, we would appreciate hearing from you. We will gladly provide information on where or how to search for these grebes. All information or inquiries should be addressed to Eichhorst. 


\section{Acknowledgements}

Mike Anderson kindly allowed us to camp-out and use the facilities at the Delta Waterfowl and Wetland Research Station. Miles Ward granted permission to work on the East Marsh. The students and staff at the station made our stay most enjoyable. Our field work was funded in part by a Frank M. Chapman award and a University of North Dakota Doctoral Research Fellowship to Bruce Eichhorst.

\section{AMERICAN ORNITHOLOGISTS'} UNION. 1983. Check-list of North American birds, 6th ed. Washington, D.C., American Omithologists' Union.

2. 1985. Thiny-fifth Supplement to the American Ornithologists' Union check-list of North American birds. Auk 102:680686.

3. ANDERSON, M.G. and R.E. JONES. 1976. Submerged aquatic vascular plants of East Delta Marsh. Manitoba Dept. Renew. Resour. and Transp. Serv., Wildl. Rep.

4. BAIRD, S.F. 1858. Birds. In Reports of explorations and surveys to ascertain the most practicable and economical route for a railroad from the Mississippi River to the Pacific Ocean, vol. 9, pant 2. Washington, D.C., Ex. Doc. No. 91.

5. DE SMET, K.D. 1987. First nesting record and status of the Clark's Grebe in Canada.
Blue Jay 45:101-105.

6. FOOTE, A.L. 1989. Response of nesting waterfowl to flooding in Great Salt Lake wetlands. Great Basin Naturalist 49:614617.

7. GOLLOP, B. 1987. Prairie Provinces region. Am. Birds 41:1451-1453.

8. 1988. Prairie Provinces region. Am. Birds 42:1304-1305.

9. 1989 . Prairie Provinces region. Am. Birds 43:1330-1332.

10. KOES, R.F. and P. TAYLOR. 1990. Prairie Provinces region. Am. Birds 44:1148-1149.

11. NUECHTERLEIN, G.L. 1975. Nesting ecology of Westem Grebes on the Delta Marsh, Manitoba. Unpubl. M.S. thesis, Colorado State Univ., Fort Collins, Colorado.

12. 1982 . Westem Grebes, the birds that walk on water. Nat. Geogr. 161:624-637.

13. SZAFRANSKI, K. 1989. Photo contest. Nat. Wildl. 27(1):50-51.

14. WALKER, J.M. 1965. Vegetation changes with falling water levels in the Delta Marsh, Manitoba. Unpubl. Ph.D. thesis, Univ. of Manitoba, Winnipeg, Manitoba.

And I brought you into a plentiful country, to eat the fruit thereof and the goodness thereof; but when ye entered, ye defiled my land, and made mine heritage an abomination. Jeremiah 2:7 (Peter Matthiesseon. 1959. Wildlife in America. Title Page)

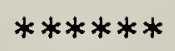

There is not so contemptible a plant or animal that does not confound the most enlarged understanding. John Locke. 